\title{
Improving the Writing Skills of EFL High School Learners through Alternative Methods of Assessment and Differentiated Instruction
}

\author{
Theodora Argyropoulou \\ B. A in English Language and Literature and M.A. in The Teaching of English as a \\ Foreign/International Language. English Language Teacher at Polykastro Junior High School. \\ Pontou 4, 61400, Axioupoli

\section{Makrina - Nina Zafiri} \\ Permanent at the Aristotle University of Thessaloniki, Office of Foreign Languages, Teacher \\ Trainer at the National Teacher Training Center in ASPAITE, Thessaloniki, Academic \\ Associate at the Hellenic Open University, MA Program in the Teaching of English as a \\ Foreign/International Language.
}

Kastorias 3, 40 Ekklesies, 54636, Thessaloniki

Received: March 11, $2021 \quad$ Accepted: April 24, $2021 \quad$ Published: April 28, 2021

doi:10.5296/ijele.v9i1.18572 URL: https://doi.org/10.5296/ijele.v9i1.18572

\begin{abstract}
The study described in this article investigated EFL writing in the $1^{\text {st }}$ Grade of a State Junior High School. More particularly, the study examined whether the use of alternative assessment methods, such as self-assessment and peer-assessment checklists, in a differentiated class environment, can have a positive effect on learners' writing skills. For the needs of this research an experimental and a control group were targeted. The teaching materials which were used in the research process were differentiated according to the principles of Differentiated Instruction and learners were assigned to write different writing genres.

Findings revealed that differentiated instruction had an impact on the learners' writings. However, there were limitations regarding the time that had to be allotted in the designing of the lessons and the instruction itself. Also, the instruction was limited to a small group of learners. However, the implications of the research brought to light the involvement of the learners in the assessment process.
\end{abstract}

Keywords: Differentiated Instruction, Alternative Assessment, Writing Skill, Action Research 


\section{Introduction}

Diversity in the class is more evident than ever. Learners with a wide range of interests, learning styles and levels of readiness, are a common case encountered by teachers of different class grades throughout the world. Differentiated Instruction is the means through which the teacher embraces these differences amongst the learners. Furthermore, alternative assessment methods which differ from the traditional standardized assessment measures, which are basically norm-referenced, have gained support in the teaching field. An attempt to familiarize learners with alternative assessment methods such as self-assessment and peer-assessment checklists, has also been set. The research involved an action research in which an attempt was made to examine Differentiated Instruction in connection with students' writing skills, which is considered the most demanding in the language production.

The study examined whether the use of alternative assessment methods, such as self-assessment and peer-assessment checklists, in a differentiated class environment, can have a positive effect on learners' writing products and can raise learners' self-correctness on their written work.

\section{The Educational Context of English as a Foreign Language in the Greek State Secondary Education}

The Cross-thematic Curriculum Framework of Modern Foreign Languages (2003), also known as DEPPS construes English Language teaching within the Greek context. The aforementioned curriculum was created because there was a need to abide to the European Guidelines of the Cross Thematic Curricula (Anastasiadou, 2010).

\subsection{The Curriculum for Secondary Education}

In Greece, the curriculum addresses learners of primary and secondary education schools and it is determined by the Institute of Educational Policy. The Unified Curriculum for Foreign Languages (UCFL) is the formal Curriculum (Spinthourakis in Ayakli, Karavas, Manolopoulou-Sergi, 2004), published in the Government Gazette (2016). It includes guidelines, aims and objectives set by the European Union's policies. It is a curriculum common for all foreign languages and all levels of education and it can be classified as being an open type of curriculum (Spinthourakis in Ayakli, Karavas, Manolopoulou-Sergi, 2004), since the teacher, through the implementation of the curriculum, has a small say in the process.

Concerning the teaching of English as a foreign language in Secondary Education, the guiding principles involve the promotion of foreign language literacy, multilingualism and multiculturalism.

The communicative orientation of the curriculum is evident. It sees learners as multilingual, multicultural and literate entities, able to communicate effectively in different environments. Literacy deals with the acquisition of language functions, forms, structures and skills. Multilingualism negotiates the development of understanding the differences between speech 
and language, between different languages and aims at lifelong learning. Multiculturalism relates to the awareness of the differences between cultures and thus the differences in the perception of the world, and aims at the acceptance of other cultures and nations (Lock \& Bailey, 2014; Taylor, 1994).

\subsection{The Curriculum and the Writing Skill}

Students attending the $1^{\text {st }}$ Grade of Junior High School can be described as A2 Basic users at Waystage, according to the Common European Framework of Reference (CEFR). Aims and objectives, skills and indicative cross-thematic approaches are described, classifying the curriculum to promote a communicative orientation, as do the majority of official curricula (Enever, Moon, Raman, 2009).

Writing activities at this stage are primarily communicative and include the completion of forms and questionnaires, and writing letters, articles and reports. Learners should be able to write about aspects of their everyday life (people, places, to present their jobs, and study experiences), basic descriptions of events and past activities or personal experiences, simple poems or biographies. Learners should also be able to select the appropriate style of writing and genre in a given situation. In addition, multilingualism is evident in the writing skill where learners should be able to produce a written text in one language bearing in mind the written or oral text in the other language, or by using sample texts in one language like the mother tongue, and then producing a similar text in the target language. Finally, multiculturalism is apparent in learners' writing skills in which they are asked to produce written discourse in order to communicate.

\section{Literature Overview on Differentiated Instruction and Writing Theories}

\subsection{Differentiated Instruction and Theoretical Background}

The term Differentiated instruction first appeared around two decades ago and was mainly used for talented, gifted learners working above grade level (Hall, 2002). Its conceptual framework has its roots in Vygotsky's (1978) social constructivist theory (Subban, 2006) and cognitivism. In the last few years, research has been conducted aiming at proving that differentiated instruction can accordingly be used to learners, of different levels, interests, abilities, cultural and language differences, even learners learning at a slower pace (Nordlund, 2003).

\subsubsection{Vygotsky's Theory and the Zone of Proximal Development}

The working aspect of differentiated instruction that constitutes that teachers work with their learners and other professionals to cater for an optimum learning environment, which is reflected in Vygotsky's socio-cultural theory (Subban, 2006). The emphasis is on the importance of interaction with others in learning, which is is prominent in Vygotsky's (1978) social constructivism. The concepts of 'Scaffolding' and 'The Zone of Proximal Development' (ZPD) are met in the theory, presupposing that, sufficient input, and social interaction, lead to learning. Exposure of learners to language that is slightly higher than their cognitive level, 
when interacting with their peers or their teacher (according to Krashen's Input Hypothesis (1985), can facilitate teachers in reaching the child's ZPD. This zone is designated as the distance between the actual level of development arbitrated by independent problem solving, and the level of potential development through adult guidance or peer collaboration.

Furthermore, learners who are seen as parts of a cultural and social background are the ones who assign meaning to information newly acquired, since previous knowledge and experiences are the basis upon which it is built.

What is more, interaction with peers and the teacher at a level slightly above their cognitive capacities should be enhanced. However, caution on the selection of tasks should be allocated so as to prepare tasks of a moderate challenge. According to Tomlinson (1999), a difficult task for the learner, may lead to feelings of threat, thus shifting into a self-protection mode and refusing to deal with solving it. On the other hand, simple tasks, lead the learner to a more relaxing mode of learning, where the student feels safe and confident in dealing with the tasks.

Differentiated Instruction treats learners as unique, acknowledging their different cultural and social backgrounds. The concept of student 'readiness', a concept important in differentiated instruction, is established in Vygotsky's 'Zone of Proximal Development'. In a differentiated class learners are augmented in reaching their zone of proximal development.

\subsubsection{Gardner's Multiple Intelligences Theory}

According to Gardner (1999), there are eight types of intelligence, "visual-spatial, verbal-linguistic, musical, logical-mathematical, bodily-kinesthetic, interpersonal, intrapersonal and naturalistic" (Davis, Christodoulou, Seider, \& Gardner, 2011). They all exist in a person; however, one is usually prevalent, with a greater impact on the acquisition of the process of knowledge. Hence, in order for a teaching context to be effective, all learners' types of intelligences should be catered for. Grigorenko and Sternberg (1987), supported that instruction that is matched to the learners' practical, analytical and creative learning model, is fundamental in learner achievement, even if the tasks are slightly modified (Sternberg, 2003).

In differentiated instruction environments, all types of intelligence can be cultivated (Thakur, 2014).

\subsection{Definition and Key Principles of Differentiated Instruction}

Stradling and Sounders (1993) portray differentiated instruction as an approach, that paves the way for the acquisition of knowledge, content and understanding. In order for differentiated instruction to be successful, however, certain principles need to be followed. Firstly, differentiated instruction calls for tasks which cater for the needs of learners bearing their readiness level, learning preferences and interests in mind. Also, differentiated instruction is learner-centered. The teacher coordinates time, tasks, materials, but the learners are the workers (Tomlinson, 1999). The teacher is the one who contemplates each learner's 
characteristics, to respect them and to accommodate them in order for learners to engage in the learning process (Roberts \& Inman, 2013).

Furthermore, differentiated instruction is pro-active. Preceding the implementation of any tasks, investigation of the learners' cognitive level, their interests, preferences, strengths and weaknesses, is of primary importance. The starting point of each learner is the basis of the creation of the appropriate material on the part of the teacher so as to cater for their individual differences (Kanevsky, 2011; Tomlinson \& McTighe, 2006).

Moreover, differentiated instruction is relevant to each learner. Whatever new is presented, is relevant to what the learner already knows (Carrel \& Eisterhold, 1988). The teacher's work links this knowledge to the already existing one. Differentiated instruction is also flexible and individual work, group or pair work or work as a whole class, or as modes of work which do not remain stative, are all taken into account. Finally, differentiated instruction is challenging. It motivates learners to exceed their capacities, engaging them in a challenging form of thinking. The more a learner is interested in something, the more he is interested in learning (Brandt, 1998).

\subsubsection{Areas of Modification in the Differentiated Instruction}

The elements the teacher can modify in the application of differentiated instruction, according to Tomlinson (1999), are content, process and product.

\subsubsection{Differentiating the Content of Instruction}

The first key element is to differentiate its content. Content refers to the 'what' of the lesson (Tomlinson, 1999). It enables all ideas to be used, all skills, facts, the knowledge and information the learner should understand in order to use the aforementioned. Content is differentiated either by adaptation of what is taught or by modification of the way learners are given access to what is intended to be learned. Learners are given the opportunity to become responsible for their learning at their own pace (Heacox, 2002). One way is through providing students with alternative ways of assessing the material (Tomlinson, 2001a; 2001b) either by using text variety (simplified or authentic, print or electronic), or by providing them with text types such as articles, brochures, etc. The teacher's knowledge in helping learners to comprehend the differentiated content, is crucial, whether that involves small groups, to help struggling learners, or to challenge more advanced learners, or the use of specific material according to the type of learner (visual, auditory, kinesthetic) (Champan \& King, 2005).

\subsubsection{Differentiating the Process of Instruction}

The second area to differentiate is the process. Process refers to the 'how' of the teaching (Tomlinson, 1999). It has to do with differentiating the way learners are going to work with the content. The teacher's decision on the objectives of a lesson and how they will be accomplished is central (Bailey \& Williams-Black, 2008). Various learning strategies and activities are provided to learners to explore concepts (Theroux, 2004). These include learning centers, time manipulation and variety according to the learners' needs, as well as flexible grouping, but also the use of different tasks according to the learners' abilities, 
interests, and needs. Tiered tasks are also used when the teacher wants to ensure that learners with different learning needs, work upon the same skills and ideas (Tomlinson, 1999). None of the above would be possible without acknowledging the most important factor, which is that of choice. The learners choose how they will interact with the information given, and the tasks they are provided with should offer ways to explore the content and decide on the mode of their work, alone, in pairs or in groups.

\subsubsection{Differentiating the Product of Instruction}

The third area to differentiate is the product. Product is 'what learners produce' to exhibit knowledge mastery (Tomlinson, 1999), in other words, it is the output that indicates what the learners have acquired. Providing learners with a variety of items that will illustrate what has been learned, is an aspect which teachers can differentiate (Knowles, 2009). According to Bailey and Williams-Black (2008) when a teacher differentiates the product, learners can self-select the way to show they have acquired what was meant to be learnt. Products are articles, brochure reports, or dialogues, songs, multimedia presentations (Kingore, 2004), debates, even mock trials (Heacox, 2012).

\subsubsection{Differentiation according to Students' Characteristics}

\subsubsection{Differentiating according to Readiness Level}

Readiness refers to the learner's access point in understanding (Tomlinson, 2014). When differentiating according to readiness, the teacher varies the degree of difficulty and complexity of the tasks, challenging learners of all levels and ensures that all learners are implemented with experiences that are appropriately challenging (Santangelo \& Tomlinson, 2012). Higher level learners are assigned complex and abstract activities, while less-developed learners are assigned concrete and structured ones (Tomlinson, 2003). At this point it is important to note that, since each individual may have different levels of readiness (Jensen, 1998), attention should be administered to the level of the challenge implemented upon each learner, no matter which challenging tasks are the ones stimulating the learner's brain (Gregory \& Chapman, 2013).

\subsubsection{Differentiating according to Learners' Interests}

Differentiation can also be made based on the learners' interests. If the content of learning is challenging for the learners, they feel satisfaction with what is learnt, and through engagement in the process, motivation is promoted. Intriguing and relevant issues support learners in connecting them with the new information (Tomlinson, 2003c; Torrance, 1995; Brandt, 1998). Learners of all levels are given opportunities to explore topics that trigger their curiosity and attention (Brandt, 1998). In a differentiated class, even the weak or indifferent learner finds his or her place (Lawrence-Brown, 2004.

\subsubsection{Differentiating according to Learning Profile}

Another variant of differentiated instruction is differentiating according to the learners' learning profile. Learning profiles deal with how the learner learns best (Tomlinson, 2001a; 2001b) and they are shaped by the learner's learning style, culture, age, gender and 
intelligence preference. Whether a learner prefers to work alone or in groups, is also a kind of preference that should be taken into consideration by the teacher. Also, learning profiles include interests, family poverty, learning styles, nationality, even major events in the learner's life (Wormeli, 2007) and multiple intelligences. This correlates with Gardner's (1999) Theory of Multiple Intelligences, which was mentioned earlier. Tomlinson's and Callahan's (1992) research revealed that teachers who followed an instructional approach based on Gardner's Intelligences, succeeded in meeting their learners' needs, even the ones who were not considered to belong to the traditional learner type.

\section{Writing in the EFL Context}

It is generally accepted that the writing skill is the most difficult one to acquire, and it is also the most demanding and challenging one when learning a foreign language (Richards \& Renandya, 2003; Harmer, 2007; Kurk \& Atay, 2007; Alsamdani, 2010) as it involves a number of lexical, cognitive and sociocultural capacities (Barkaoui, 2007). In order for a person to learn how to write in a foreign language, effort has to be made.

Interest in the topic students are asked to write about is essential. The teacher's role is that of the facilitator who transmits the necessary knowledge for writing successfully, besides teaching his or her learners the rules of the target language (Barkaoui, 2007). Models of writing are provided to learners, assisting their efforts in the practice of written language production.

\subsection{Approaches to Writing}

Approaches to writing involve text-based, reader-based and writer-based (Calfoglou, 2004) depending on who or what is the center of attention.

A text-based approach to writing gives emphasis to the text, the final product, promoting cohesive and coherent texts which focus on form rather than function (Hyland, 2013). Meaning in the text-based approach is conveyed through the text itself and not through reader-writer interaction (Calfoglou, 2004). Learners are given model-texts which they imitate mechanically in an attempt to improve themselves in the writing skill based on the structures of language (Badger \& White, 2000; Hyland, 2004). Focus is on grammatical accuracy thus failing to appreciate innovative ideas (Hyland, 2002). However, this approach is popular in ESP language teaching, where learners practice specific writing structures for a specific exam certificate (Johns, 2003). In light of the above, a text-based approach was adopted as tasks were designed to focus on form and function. Model texts were provided but they are not imitated mechanically.

The reader-based approach gives emphasis to the reader apart from the writer. The act of writing is an act of mutual understanding between writer-reader, so the social element is important. The writer's goal is to produce a piece of writing having the potential reader in mind. A mere expression of the writer's opinion is discouraged, while consideration of the reader's expectations, are encouraged. The reader's social context and background is a point 
to be considered. The written product should be in accordance with the reader's norms and culture (Hyland, 2003). In this light, learners produce writings with a potential audience in mind.

Finally, the writer-based approach to writing, developed by Murray (1980, as cited in Caudery, 1995) and the Expressivists, emphasizes upon the writing of a series of drafts in which the writer acts creatively, thus becoming able to discover a personal voice, but in this case, the process of writing is equal to the product of writing (White \& Arndt, 1991; Calfoglou, 2004). Meaning is conveyed with absence of control or the structural constraints of the text-based approach.

The Flower and Hayes (1981) model emphasizes upon the cognitive aspect of writing that involves negotiation and problem-solving. There are three stages proposed in the model, the planning stage, the translating ideas stage, and the reviewing stage. The writer first activates and organizes ideas, then the ideas are converted into words, written on paper in drafts and, in the end, the writer reflects on the draft and edits it.

White and Arndt (1991) proposed six stages in the writing process, generating ideas, focusing, structuring, drafting, evaluating and reviewing. The writer interacts with the text and the reader in an on-going process. Engagement of learners in activities includes proofreading, loop writing, editing, modifying, and grouping (Calfoglou, 2004). The social aspect and the contextualization of writing is evident. Process writing provides feedback to the learner who can evaluate himself or his peers. In this specific research, a combination of the three methods is abided to, as mentioned before.

The social aspect and the contextualization of writing is evident. Process writing provides feedback to the learner who can evaluate himself or his peers. In this specific research, a combination of the three methods was abided to, as mentioned before.

\subsection{Methods in Writing}

Differentiated Instruction, which focuses on the designing of tasks for learners of different levels, complies with the tenet of the Communicative Approach which is effective because it offers learners a whole-task practice. Additionally, the approach holds, in respect, cognitive, linguistic, and social aspects of L1 and L2. As Tan (2004) emphasizes, the expectations and needs of learners should not be disregarded, but should be examined in accordance with their cultural background. This fully aligns with tenets of Differentiated Instruction in the designing of appropriate tasks. The fact that learners are given the opportunity to work in groups, also aligns with the tenets of differentiated instruction which allow flexible seating and modes of work.

\subsection{Theoretical Models of Teaching Writing}

\subsubsection{Writing as a Product}

Gabrielatos (2002) identifies the product approach as an imitation of model texts by the learners. The learners are provided with a certain structure which they are expected to follow in order to construct their own pieces of writing. The product approach involves four stages 
(Steele, 2004). In the first stage, model texts are studied by the learners with specific attention to the genre structure. In the second stage, highlighted features are practiced in isolation. In the third stage, ideas are organized. This, according to Hasan (2011), is the most important stage in product writing. In the last stage, the end product is assembled.

Based on Byrne's (1986) 'Presentation, Practice, Production' (or PPP) model, the writing lesson is developed through these stages. In the Presentation stage learners are introduced to the appropriate language through model texts. In the Practice stage, learners organize their texts with a focus on accuracy. In the Production stage, learners produce the text. McDonough and Shaw (2012) refer to the product-oriented writing approach as being the traditional way in teaching writing, where focus on explicitness and accuracy are of major importance. Attaining language competence is the goal, tasks are guided, and texts need to be error-free. According to Calfoglou (2004), writing is disembodied from context. In this context, teacher feedback focuses on the accuracy of form rather than on the personal expression of the writer (Susser, 1994), thus inhibiting communication.

\subsubsection{Writing as a Process}

Seen in the light of Taylor (1981) and Zamel (1982), writing is a circular, not a linear, process. Kroll (1990) defines the process approach as an "umbrella term" of different types of writing. The approach the learner writers are involved in is cyclical, and the learners go through various stages rather that a single and complete response.

\subsection{Writing in the Differentiated Classroom}

Having in mind learners' different interests and writing performances, differentiated writing instruction can be beneficiary according to the learner's ability level (Badger \& White, 2000). First of all, differentiated instruction provides the learners with the opportunity of choice. As Eyers (1996) pinpoints, when learners are free over what to write, they become more motivated. Furthermore, when the teacher differentiates the content and adjusts instruction according to the learners' needs, this is, in a way, planned. Also, learners are given the opportunity to choose their writing activities, which are based on their interests, intelligences and preferences.

\section{Assessment in Differentiated Instruction}

The notion of assessment is prominent in differentiated instruction and it is ongoing (Tomlinson, 2014) and diagnostic. In differentiated instruction, assessment deviates from the traditional role of assigning it at the end of a unit and it is assigned a threefold tenor; it begins with pre-assessment when gathering information before a unit study; it moves on to ongoing or formative assessment throughout the unit study, and ends with summative assessment in the end of a unit of study.

Diagnostic assessment is the starting point of learners' background knowledge, skills, preferences and interests. For the needs of this research, a questionnaire was distributed to the learners to evaluate the level of language acquisition, and a pre-test to assess their written 
texts.

Ongoing or formative assessment is the evolution stage of learners' background knowledge, skills, preferences and interests (Richards, 2001). Additionally, alternative assessment encircles formative assessment through the process of continuously collecting information on the learners' language (Tsagari, 2008). In this particular research, self- and peer- assessment checklists were administered. Benson (2011) advocates that self-assessment checklists allow learners to take on their responsibilities and thus acquire a perception of independence.

Summative assessment is the evaluation of the level the learners have reached at the end of the instruction. Learners should be informed about whether they have reached the set targets. In this way, they are encouraged to take the next step. According to Zhao (2010), assessment in writing should be seen as a tool for learning, not just for focusing on examination standards. For the needs of this research, marking criteria of the KPG writing exam were used to assess learners' writing performance. In particular, an adapted 15-point scale assessment grid was used to assess the pre- and post- test. A separately adapted 25-point scale was used to assess the learners' written texts.

According to Hall, Vue, Strangam and Meyer (2003), successful differentiation derives from meaningful pre-assessment and the combination of pre- and ongoing assessment, which provides the teacher with various choices, opportunities, and scaffolding for the diverse needs of his or her learners. What is also prominent is that differentiated instruction is valuable to alternative assessment. Hamayan (1995) asserts that alternative assessment is the means to improve instruction by providing the teacher with, not only data on learner performance, but also feedback on their skills. Through assessment, the teacher is provided with rich data either on their interests, or on their readiness and skills. The teacher modifies the instruction accordingly and through interaction with learners, metacognitive strategies are employed leading to autonomy (Benson, 2011. For the needs of this research, two alternative assessment methods were used, self- and peer- assessment, because they offer the opportunity to learners to be assessed in the product and the process of writing.

\section{The Teacher's Role in Effective Differentiated Instruction}

When conducting differentiated instruction teachers undertake various roles. First of all, they are the organizers of the process, the people who are responsible for the transformation of the curriculum and who investigate learners' interests and styles. They discuss matters of interest with their learners and encourage them to use alternative assessment methods.. In this way, the teacher-learner relationship is enhanced. Through the learning process, both the teacher and the learners monitor the progress of the latter (Hancock, 1994, as cited in Hamidi, 2010), and through self-reflection, learners assess themselves (Moon, 2000).

\section{Action Research Methodology}

\subsection{The Research Method}


As mentioned in the beginning (the introduction section) of this research, the research questions that were posed were the following:

a) Can a differentiated approach to writing lead to improved writing skills?

b) Can a differentiated approach to writing lead to raising learners' self-correctness on their written work?

c) Can learners familiarize themselves with the use of self-assessment and peer-assessment checklists to help themselves and their peers in writing effectively?

d) Can self-assessment and peer-assessment checklists help learners become autonomous writers?

The purpose of this research was to investigate whether differentiated instruction can improve learners' written work, with a focus on the assessment of learners' work using alternative methods. The medium used to conduct this research was an action research.

Burns (2010) explains that action research consists of four stages. During the planning stage the researcher, having in mind specific instruction goals, designs the intervention process. At the acting stage, the intervention is performed. The observation stage involves the records made by the research with reference to any changes in the behavior of the participants. At the final reflecting stage, the researcher draws conclusions on the effectiveness of the process and further action to be taken.

\subsection{Action Research Procedure}

For the needs of this research, a pre-test was prepared and administered to the experimental group in order to determine their level of English language. The chosen pre-test was a past examination paper which was taken from the KPG exam, and this was done for reasons of reliability and validity. Learners were examined on their writing skills, so only one part of the test was selected for administration. Since learners are Basic users at a Waystage level, the pre-test confirmed their level.

Four lessons of approximately 100 minutes were prepared. Each designed lesson was differentiated according to the principles of differentiated instruction and corresponded to a different writing genre. At the end of each lesson, the learners were administered either a selfor a peer-assessment checklist, with features of the specific writing genre. The first lesson was designed according to learner readiness and the principles of differentiated instruction which were followed, namely the Tiered Tasks. The tasks guided learners in writing an email about their ideal school and the alternative method of assessment which was applied was the self-assessment checklist. The second lesson, was also designed on the basis of the learners' readiness level where, again, the Tiered Tasks principle was involved, and the genre they were guided to write about was an article. Again, learners were assessed through the use of a self-assessment checklist. The third lesson was designed on the basis of the Cube Principle and was differentiated in its content and the product. Learners were asked to write a letter of advice addressed to a person of their choice but dealing with a specific problem that came up after the rolling of the cube. The task sheet was common for all learners. At the end of the 
instruction, learners were asked to assess their peers through the use of a peer-assessment checklist. The fourth and final lesson, was designed through differentiating the process and the product of the writing and was based on the strategy of the Entry Points. Learners were grouped according to their learning profiles that originated from the pre-questionnaire assigned before the beginning of the instruction process. The tasks led learners to write a short story. The task sheets were different according to each Entry Point. At the end of the lesson, learners assessed their peers again through a peer-assessment checklist.

The action research was completed with the questionnaires which were distributed to the experimental group and a post-test of the KPG exam.

\subsection{The Participants of the Research}

The research involved a group of 12-year-old-learners attending the First Grade of Junior High School. Their level, according to the Common European Framework of Reference (CEFR, 2001), can be described as Waystage/A2. All learners attended English for two 45-minute classes a week. Learners were divided into two groups. The one group was the control group and the other the experimental group, composed of eleven learners, eight boys and three girls. The teaching procedure the experimental group participated in, involved three stages, the pre-instruction stage, the instruction stage and the post-instruction stage. During the pre-instruction stage, a needs analysis questionnaire was answered by the learners so as to investigate their preferences in learning, their needs, their learning style and their attitudes towards writing. Furthermore, a pre-test was administered before the instruction which gave the teachers insight regarding the learners' readiness level. At the post-instruction stage, a post-test was administered which was the same as the pre-test, in order to account for the improvement in their writing, and the potential benefits which they gained from the differentiated instruction. For reasons of validity and reliability, as mentioned earlier, the KPG exam format was selected.

\subsection{The Research Instruments}

For reasons of data triangulation and validity (Dornyei, 2007), a combination of quantitative research instruments, was applied. A pre-questionnaire, the learners' self- and peer-assessment checklists, the grades of the participants' writings and the post-questionnaire, were applied.

\subsubsection{Quantitative Instruments}

Quantitative research involved a pre- and a post- questionnaire administered to learners before and after the intervention. The questionnaire provided the teachers with insight on the preferences and learning styles of their learners.

A learner friendly approach was followed, using emoticons that learners are familiar with. The introduction at the beginning of the questionnaire, informed the learners on what they had to do. Furthermore, anonymity was insured, and there was also reassurance that there would be no assessment involved, since there were no right or wrong answers. According to Dörnyei (2003), confidentiality attributes to sincere answers. 
Demographic data was gathered in the first part of the questionnaire. Gender questions, and questions regarding the teaching of the English language, were also set. What followed is a distinctive grouping of questions associated with motivation, learning preferences, and strategies.

In the first category of questions that were formed, learners were asked about the reasons why they were learning English. A variety of questions both targeted towards intrinsic motivation, which concerns what comes into existence inside the class (Harmer, 1991) and extrinsic motivation, which concerns factors which exist outside the class (Harmer, 1991).

In the second category, a set of questions targeted to learning preferences and interests, was selected. Focus was on covering all learning styles according to Gardner's (1999) Multiple Intelligences, so a variety of questions concerning the way learners prefer to be taught, was applied. Findings reported four learning types, narrative, logical, aesthetic and experiential, so a lesson was prepared based on these specific types. Additionally, attention was paid to the writing skill, applying a set of questions to acquire insight into genres learners prefer to write about.

The third and final category was dedicated to the writing strategies employed in the writing process. It involved questions regarding the activation of background knowledge, predicting, and self-evaluating.

A post-questionnaire was distributed to the experimental group at the end of the instruction. The role of the questionnaire was multifold. Firstly, it revealed if their initial preferences, regarding their writing topics, had changed. Also, it affirmed whether learners have indeed learned how to distinguish between the different writing genres and their norms. Furthermore, the post-questionnaire would indicate improvement in the writing skill and, finally, it would exhibit the point to which learners have begun to develop their writing strategies. Last but not least, the post-questionnaire demonstrated the learners' beliefs on evaluating through selfand peer- assessment checklists, and on the other hand, it revealed that learners obtained a more critical view regarding alternative assessment methods. The main tenor of the selection of the post-questionnaire was for triangulation purposes. The pre-questionnaire revealed that learners' writings are usually assessed by the teacher, and the self-evaluation process is somehow unknown to learners. The assessment grid, used to mark the pre- and post- tests, was divided into two categories. One category dealt with task completion and the other with grammar and vocabulary accuracy in language performance. Similarly, the assessment grid, which used to mark the learners' writings, was also divided into two categories. The first had to do with task completion and the second with language performance. The aspects of language, where focus was bestowed upon, were grammar, vocabulary, spelling and appropriacy. In order to render the quality of the texts produced measurable, an analytic scoring scheme was developed. This allowed for the separate evaluation of each of the criteria (Nitko, 2001). The descriptors guided the rater to consider specific features (Hyland, 2003a) and the results provided diagnostic information about ones' performance (Hughes, 2003). The scales represented assessment at a multidimensional level (Mertler, 2001), but also reflected on the marking scheme employed in lower secondary education, and, since it is 


\section{Al Macrothink}

familiar to teachers, it reduced rater subjectivity.

\section{The Research Findings}

\subsection{Collection of Data, Descriptive Analysis}

The data of the particular research was gathered from two sources. The first source was the pre-questionnaire and post- questionnaire which was distributed to the learners before and after the differentiated instruction. The second source was the pre-test and post-test.

\subsection{The Pre-questionnaire and Post-questionnaire Results}

Before the beginning of the differentiated instruction, a questionnaire was distributed to the learners so as to define their needs.

The answers provided the researchers with useful information in the designing of the differentiated instruction lessons. The majority of the learners had been learning English for 5 years, mainly outside their school environment, and in particular at a Private language Institute. Helpful insight was also provided regarding the motivation of learners for learning English.

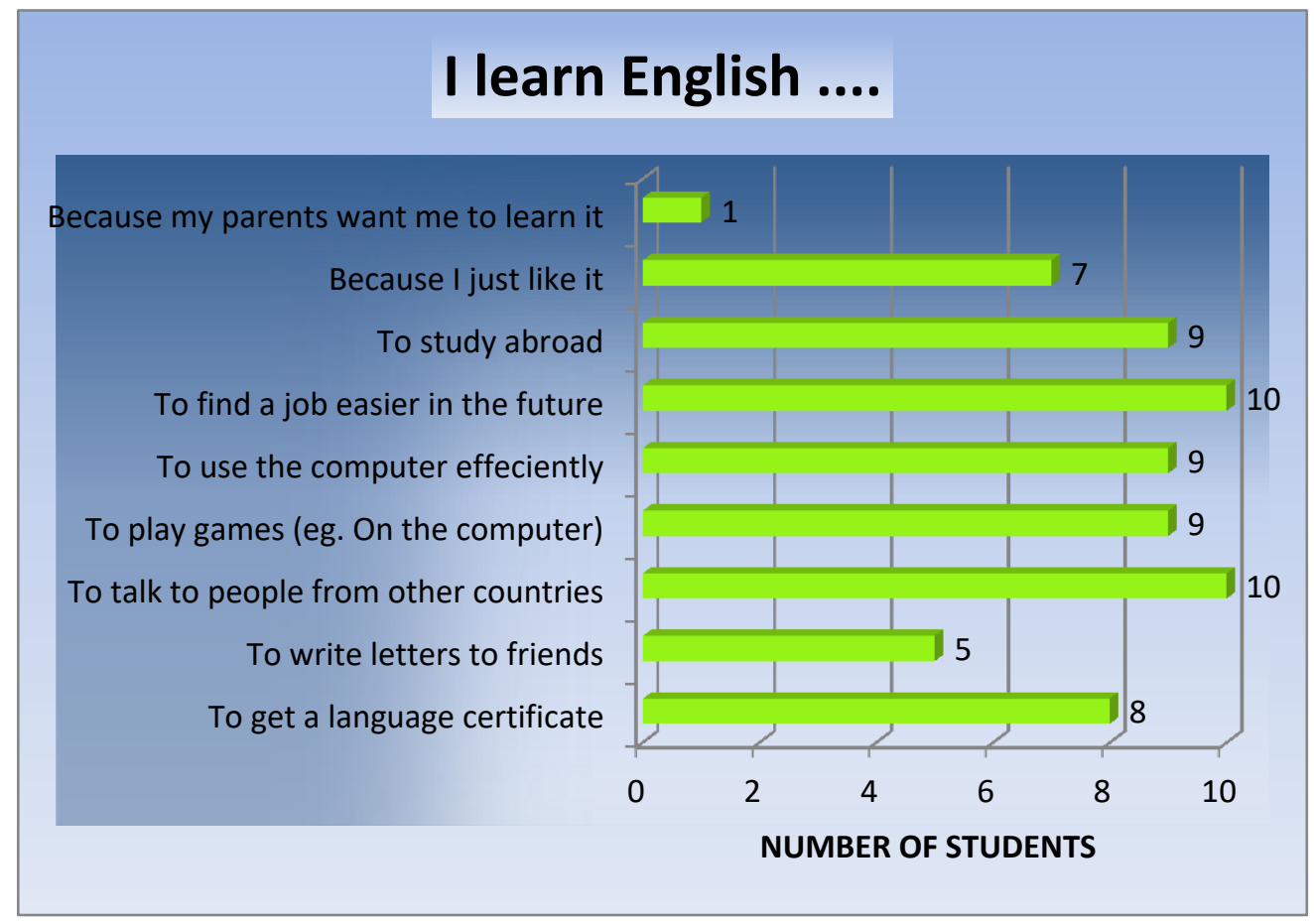

Graph 1. Reasons for learning English

The majority of the students, 10 out of 11, were interested in acquiring a certificate in English in order to find work more easily in the future, to study abroad or to talk to people from other countries. What is also worth noticing is that ten out of the eleven learners learn better by writing down the new words; perhaps it is because they use certain mnemonic techniques where they create images in their minds that link, in a way, the new word to another one that 
sounds similar to a word they know from their first language (Anderson, 1994). They also learn by reading books, and through their teachers' guidance, which confirms Todd's (2002) theory according to which the teacher distances himself or herself from involvement and is assigned the role of the facilitator who guides the learners in attaining a sense of reassurance and confidence in the learning process. The option of grouping learners, guided the teachers into assigning group work during the instruction process. Furthermore, Reid (1993) emphasized that collaborative work among learners, especially working in small groups, could be beneficial for generating ideas, peer reviewing and organizing the material.

The majority of the learners selected the short story as their favorite writing genre.

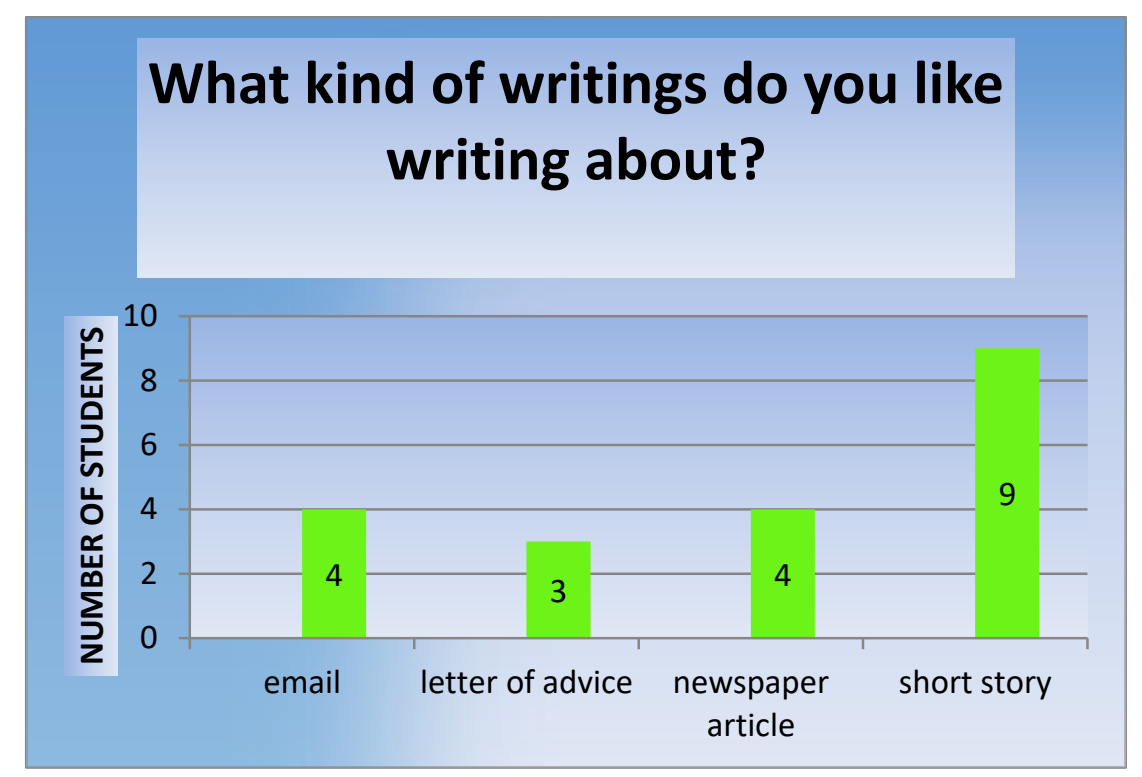

Graph 2. Favorite writing genres

This could be due to the fact that stories reminded them of fairytales and also raised their awareness of other kinds of celebrations and cultures. Through them learners delved into an imaginary world in which they enjoyed the learning process (Cameron, 2001). However, they scored poorly. Furthermore, confidence encouraged learners to confirm that they do know how to begin and end a friendly letter. Friendly letters are associated with "real-world" contexts. Also, teaching writing through categories that are schematic, can be a manageable teaching practice (Candlin \& Hyland, 1999), which was validated by the correction of their writings.

When questioned on what they want to improve, the majority selected punctuation, capital and lower-case letters, vocabulary and word description, in both the pre- and the post-questionnaire. This is indicative of the fact that they felt no work was done and that they needed further assistance. The final question revolved around the modes of work, on the written assignments, which the learners followed, and their answers included the majority of learners discussing the subject of writing with their classmates and asking for the teachers' help. In the post-questionnaire, the selection of asking for their teachers' help was minimized, while learners' confidence on 'what' to write and 'who' to write to, was maximized which could perhaps be happening because the design of the activities was clear and straightforward 
with sufficient exemplification.

Finally, it is worth mentioning that all learners liked the differentiated instruction lessons. They also liked the teachers' instruction, the group work, the use of the computer and the exercises in general.

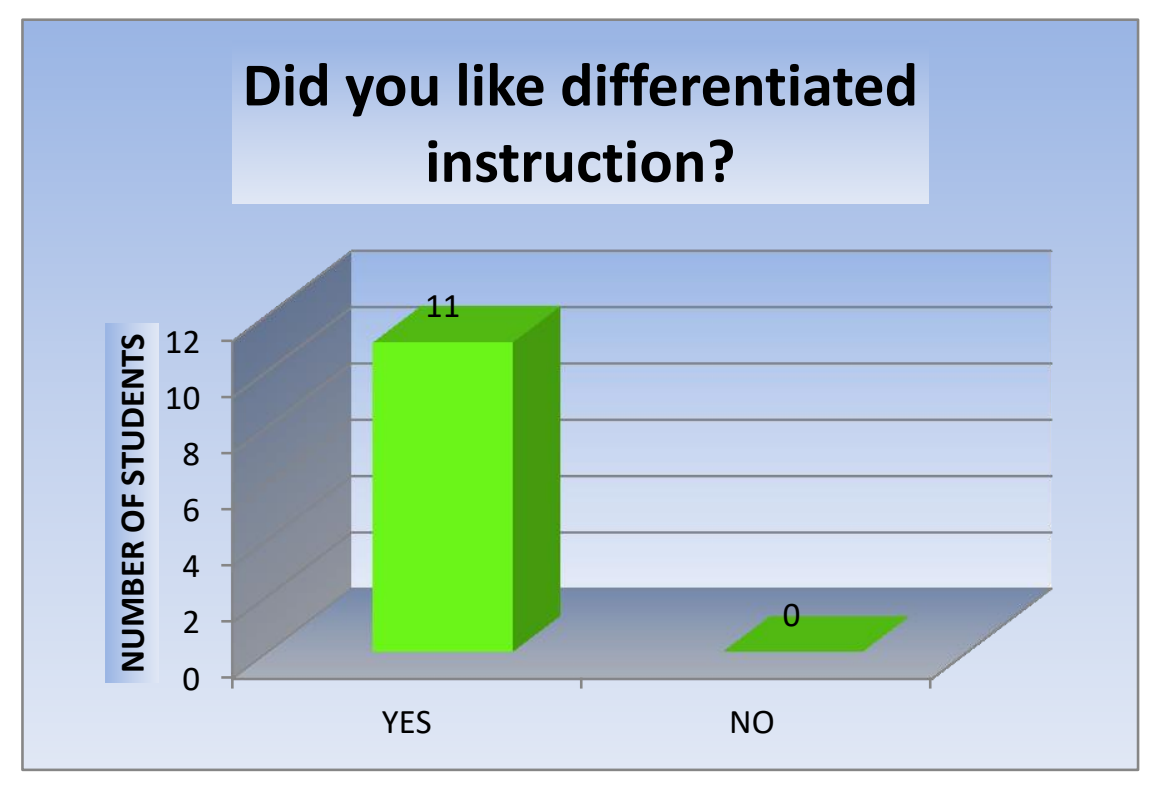

Graph 3. Differentiated Instruction preference

This could be indicative of boosting learner motivation, fully applying to Grimes and Stevens's (2009) theory which claims an increase in learner engagement and motivation. Learners liked the innovation because it deviated from a traditional method of teaching. The final question was posed in order to validate the previous one. It involved what they liked the least about their lessons, in which case the majority answered, as was expected, the contrary choices. This ensured the reliability of the research, since consistent results were gathered (Nunan, 1999).

\subsection{The Pre-test and Post-test Results}

Learners' writings were assessed by their teachers using a modified KPG-based assessment criteria grid. A ranging marking band which was divided into three subsections was used with a maximum of 15 points.

The examination of the results of the pre-test and post-test grades indicated a slight improvement in the learners' writings. 


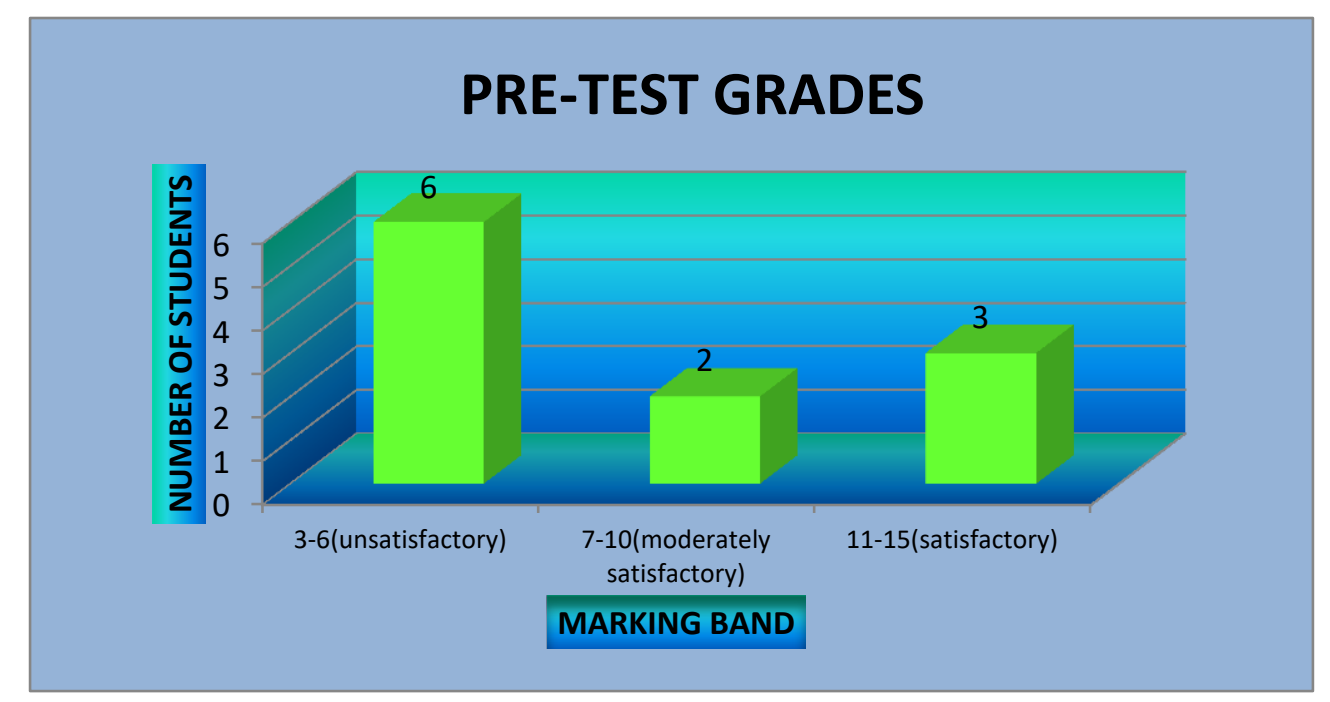

Graph 4. Pre-test marks

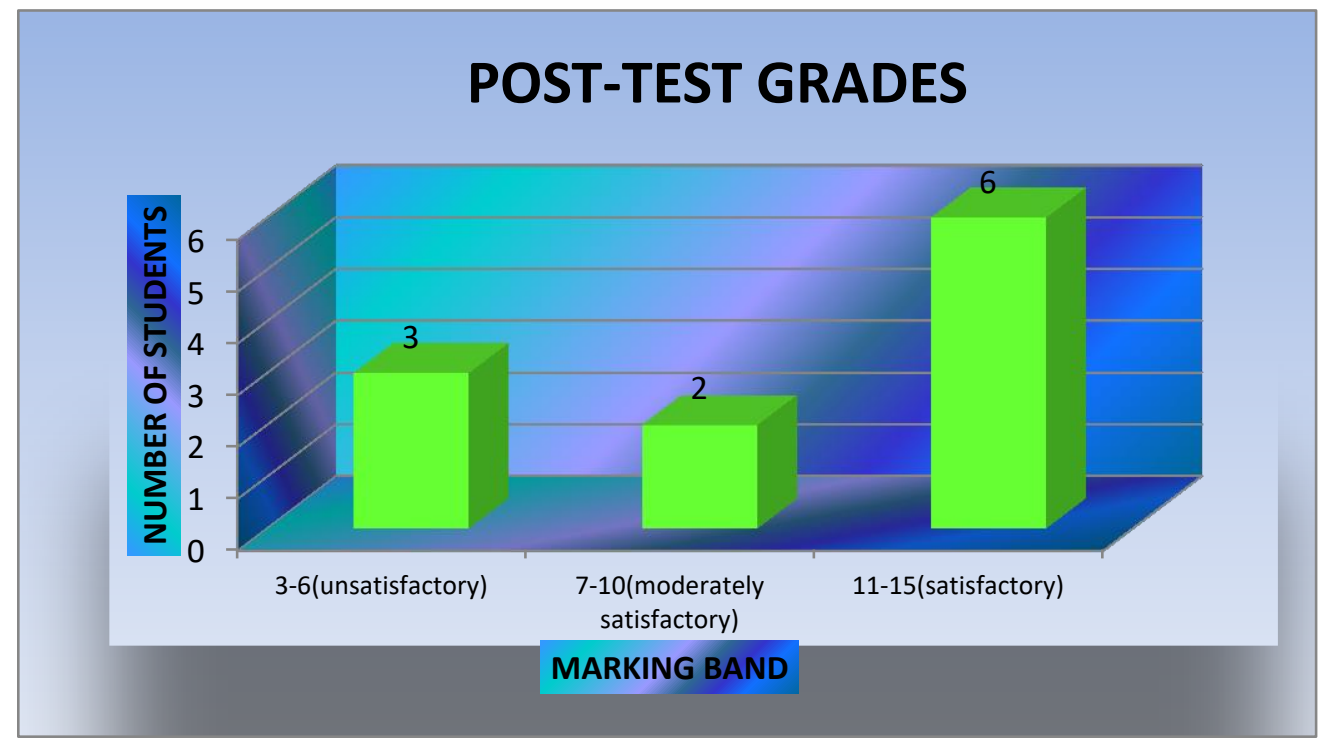

Graph 5.Post-test marks

A considerable number of learners of the experimental group scored a minimum grade ranging from 3 to 6 points in the pre-test. Results of the post-test, however, revealed that the majority of the learners, 6 out of 11, scored a maximum grade ranging between 11-15 points. This is indicative of the fact that there was a significant rise in the final post-test grades of the experimental group, which is evident in the table of the grade point average.

The genre in which learners attained lower grades, was the article, both in the pre- and post-writing stage.

\subsection{Peer-assessment and Self-assessment Checklists}

At the end of each genre instruction, the learners completed two self-assessment and two 
peer-assessment checklists which included questions on strategies regarding the writing genres. Since learners were unfamiliar with the use of checklists, the teachers who were also the researchers demonstrated the application of the letter self-assessment checklist in a separate teaching session. The most striking feature noticed in the analysis of the results was the point where learners filled in the peer-assessment checklists, in this way evaluating their peers' writings. They managed to apply the assessment criteria on the writings of their peers. Hence, they managed to indicate features which their peers failed to display, or succeeded in demonstrating. As admitted by learners, they were prompted by the self-assessment and peer-assessment checklists' cues to a large extent. This coincides with the results in Argyropoulou (2014), where self-assessment checklists assisted learners in the revising and editing of their writing texts. Their attitude towards correcting their peers and cooperating changed, thus validating Vygotsky's (1978) sociocultural theory administering that assessment was implemented, not judgmentally, but as a means of helping each other. Moreover, peer-assessment is fundamental for learner autonomy and, consequently, the language class. Additionally, the learners' bond of friendship comes forward as a means of preventing young learners from having competitive feelings towards each other (Wentzel, McNamara-Barry \& Caldwell, 2004).

\section{Discussion of the Findings}

What follows is a discussion of the research findings.

\section{a) Can a differentiated approach to writing lead to improved writing skills?}

The first question dealt with in the research involved the potential improvement of learners' writings through differentiated instruction. The findings indicated a rather stable overall score in their writings and a small improvement in their post-test. The genre the learners were more familiar with, the friendly e-mail, remained unaltered. What is worth pointing out is the fact that learners did not achieve greater scores in the short story writing, which they found to be the most difficult. As Lee (2013) states, learners need explicit teaching strategies in the writing of a story. The activity has to be clearly defined and stages need to be specified so that learners can be helped in achieving their ultimate goal in writing. This has to do with the fact that free writing is considered to be more difficult. Potentially, learners need a different input type such as for example a pre-listening activity where they could keep notes, or watch a video of a short story with no sound or subtitles. Also, suggestions could be made for more vocabulary activities, varied samples of short stories, and ready-made material. As Evgeni (2016) pinpoints, differentiated instruction with a focus on vocabulary, has a positive impact on understanding new words. Also, the learners who were considered high achievers, managed to preserve their high level. This agrees with Zare-ee's (2009) consideration that proficient EFL learners can benefit more from a genre instruction that is more explicit. This might be the case with the specific group of learners who are already high achievers and, hence, are more competent with familiarizing themselves with genre conventions of the tasks at hand. 
b) Can a differentiated approach to writing lead to raising learners' self-correction on their written work

What was quite evident through the whole differentiated instruction process, was the willingness of the learners to collaborate. Although there was evidence from the questionnaires that some learners preferred working alone, in the course of time they were the ones asking the teachers to assign them to work in pairs or groups. Especially when the learners were distributed the peer-assessment checklists, they anticipated their classmate's corrections. One of their most favorite feature, in the instructional process, was pair and group work, especially at the end of the writing genre instruction where learners had to complete their checklists. Alternative assessment promoted self-realization through group work and responsibility assignment as group members. There was respect for the group and willingness to cooperate. Interaction with fellow learners was promoted, adding to learners' enthusiasm and increasing motivation levels.

c) Can learners familiarize themselves with the use of self-assessment and peer-assessment checklists to help themselves and their peers in writing effectively?

Learners' eagerness to either assess themselves or their peers was evident from their reactions before distributing the sheets. As Lalande (1982) explains, it is because learners feel they learn more, and through self-monitoring, they improve in their writings. What was also evident was the complete absence of negativity, reluctance and hesitation in the whole process. The distribution of the assessment sheets, either to assess themselves or their peers, gave learners the opportunity to improve. This could also be due to the fact that the criteria for assessing was known to the learners, which is in line with Price's (2005) theory that criterion-referenced assessment, on the one hand, and sharing the assessment standards, on the other, are meaningful. However, some learners need more guidance in the use of grids.

\section{d) Can self-assessment and peer-assessment checklists help learners become autonomous writers?}

Although learners' attitude towards alternative assessment was favored, their answers in the post-questionnaire revealed persistence in their opinion that their teachers should correct their writings. With reference to the participants' preference to teacher-feedback compared to peer-feedback (Yang, Badger \& Yu, 2006; Zhang, 1995), it is noted that teacher-feedback is more effective than peer-feedback (Srichanyachon, 2011). This could obscure the learners' immaturity or unpreparedness to acquire the role of the assessor, and in particular, the role of the peer-assessor (Leki, 1990). As the learners who participated in this research were Greek, they were accustomed to their teachers as being in the center of the assessment process. It seems that a lot of work still needs to be done to reach a turning point to this reality.

The fact that learners avoided answering that a peer or they themselves correct their writings, probably shows their unwillingness to experiment with new tactics and that more practice was needed. In order for them to become accustomed to new tactics, more practice and social change and development is still necessary (Bourn, 2015). Their improvement in their writings, however minimal, was indicative of the first signs of their autonomy. 


\section{Mll Macrothink \\ International Journal of English Language Education \\ ISSN 2325-0887 \\ 2021, Vol. 9, No. 1}

\section{Limitations of the Study and Teaching Implications}

\section{Limitations of the Study}

Limitations of this particular study include the small number of learners who participated in the research. Also, due to the early closing of the Greek schools because of COVID19, the instruction of the control group remained incomplete. The comparison was conducted amongst learners' pre-intervention and post-intervention writings in the experimental group, focusing on the differences of the learners' pre- and post-test-grades. Moreover, the pre- and post-test involved an e-mail, whereas learners were instructed on four different genres. If the pre- and post-test involved four different writing genres, the intervention might have been more promising. Although the research showed a slight improvement on the learners' writings, the study involved a small-scale research of a sample group of learners. Additionally, Differentiated Instruction was targeted to a specific group of learners who are of a specific language level and it was conducted under controlled situations. Thus, the results cannot be generalized and cannot depict the Greek teaching reality. It also means that the results can only be interpreted subjectively.

Another factor that should be taken into consideration was the time limit. Time was limited not only for the needs of the instruction which needed to be carried out, but also for the teaching time which was spent within the class. Furthermore, a great deal of time was allocated for the preparation of the lessons by the teachers. It has to be noted that writing is a very demanding skill and, apart from the appropriate material, greater effort, on the part of the teachers and the learners, had to be made.

\section{Suggestions for Further Research}

\subsection{Implications of Differentiated Instruction}

It is commonly accepted that differentiated instruction is an approach in which a great deal of work needs to be done by the teacher and the learner in order for the learner to reach a satisfactory level (Hertberg \& Davis, 2009). Discussion on how the techniques that the teachers are taught, regarding differentiated instruction, and how these techniques can be implemented, should also be made.

\subsection{Genre Implications}

It is a fact that differentiated instruction in teaching, managed to make the learners slightly more aware of the genres of writing, and has proven to be very constructive. Learners who participated in this research became active participants, thus moving to learner-dependent learning. The language they used was genre-language and the ideas they selected were genre-appropriate.

On the teacher's part, he or she should take advantage of the work that can be done inside the class to provide learners with sufficient input. When the teacher directs the learner to meaning, eventually he or she becomes ready to transform the input he or she accepts into 
intake (Krashen, 1982). The exploitation of several types of texts, to familiarize learners with different genres, could be designed.

\subsection{Genre and Assessment Implications}

The overall assumptions from the research regarding the assessment process, revealed familiarity of the learners with the checklists and a better understanding of the expectations of the writing genres. The adjustment deviates from appropriating the texts to the expectations of the teachers, to appropriating the texts to the learners' own goals. Learners became involved, in an implicit way, in the assessment process, thus moving towards autonomy and learner-centeredness (Finch, 2007). Through integrating self-assessment and peer-assessment with traditional assessment, a more fair and global approach is assigned to assessment.

\subsection{Checklists Implications}

The genre-based checklists that were assigned in the self- and peer-assessment process were indicative of the problems that arose when writing specific genres. This prepares learners and makes them aware of potential problems which they may face or points that need to be kept in mind when writing. When given lists, learners are assisted to locate the focus points of each genre. They are responsible for their lists and the same goes for their tasks. They are the ones who plan further in their writings (Yoshimura, 2009). From the teachers' part, there is $\alpha$ need to train and to coach the learners in using the checklists.

\section{Conclusion}

The desire to investigate the potential benefits of Differentiated Instruction in the writings of First Grade learners in a State Junior High School incited the particular action research. It is an approach that can be characterized as promising, engaging participants in the learning process. The content and the structure of the class can be reexamined in a way that will allow the learners to benefit (Subban, 2006).

The process followed was that of instructing two groups of learners, a control group and an experimental group. Both groups were tested on a KPG exam and their writings were examined before and after the intervention. Additionally, the learners' attitude towards differentiated instruction was investigated, providing the researchers with information that leaned towards a positive attitude in favor of the instruction. What is more, an exploration of alternative assessment methods and their effectiveness was rendered. The findings of this research proved the learners' willingness to participate in instruction which deviated from the traditional teaching practices. Nevertheless, there is a need to conduct a larger scale research to confirm the findings of this research.

\section{References}

Alsamdani, H. A. (2010). The relationship between Saudi EFL students' writing competence, L1 writing proficiency, and self-regulation. European Journal of Social Science, 16(1), 53-63. 
Anastasiadou, A. (2010). Implementing the process writing approach in the Englishlanguage classroom: An innovation for the development of young learners' writing skills in the Greek state primary school. Unpublished Doctoral dissertation, Aristotle University of Thessaloniki: Thessaloniki.

Anderson, N. J. (1994). Developing active readers: A pedagogical framework for the second language reading class. System, 22(2), 177-194. Available at: https://doi.org/10.1016/0346-251X(94)90055-8 (accessed 12 November 2019).

Argyropoulou, A. (2014). Using self-assessment genre-based checklists to promote student self-improvement and autonomy in writing. Unpublished Master's dissertation. Patras: Hellenic Open University. Retrieved 20 February 2020 from EAP Digital Dissertation Database.

Badger, R., \& White, G. (2000). A process genre approach to teaching writing. ELT Journal, 54(2), 153-160. Available at https://doi.org/10.1093/elt/54.2.153 (accessed 17 October 2018).

Bailey, J. P., \& Williams-Black, T. H. (2008). Differentiated instruction: Three teachers' perspectives. Navigating the literacy waters: research, praxis and advocacy. College Reading Association Yearbook (29), 133-151.

Barkaoui, K. (2007). Teaching Writing to Second Language Learners: Insights from Theory and Research. TESL Reporter, 40(1), 35-48.

Benson, Ph. (2011). Teaching and Researching Autonomy in Language Learning. England New York: Longman.

Brandt, R. S. (1998). Powerful learning. Alexandria, VA: Association for Supervision and Curriculum Development.

Bourn, D. (2015). Teachers as Agents of Social Change. International Journal of Development, Education and Global Learning, 7(3), 63-77.

Burns, A. (2010). Doing action research in English language teaching. A guide for practitioners. New York: Routledge.

Byrne, D. (1986). Teaching Oral English. London: Longman.

Byrne, D. (1988). Teaching Writing Skills. London: Longman.

Calfoglou, C. (2004) Writing: Theory and Practice. In Calfoglou C., \& Sifakis N. (Eds.), Language Learning Skills and Materials: Oracy and Literacy, Vol.2. Patras: Hellenic Open University, pp.137-261.

Cameron, L. (2001). Teaching Languages to Young Learners. Cambridge: Cambridge University Press.

Candlin, C., \& Hyland, K. (1999). Writing: Texts, processes and practices. London: Longman.

Carrell, P. L., \& Eisterhold, J. C. (1988). Schema theory and ESL reading pedagogy. In 


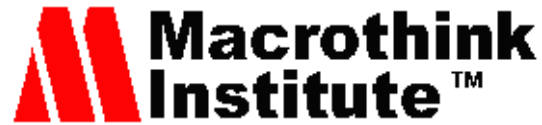

Carrell P. L., Devine J., \& Eskey D. E. (eds). Interactive approaches to second language reading. Cambridge: Cambridge University Press, pp. 73-92.

Caudery, T. (1995). What the process approach means to practicing teachers of second language writing skills. TESL-EJ, 1(4), 1-16. Available at: http://www.tesl-ej.org/wordpress/issues/volume1/ej04/ej04a3/ (accessed 22 April 2017).

Chapman, C., \& King, R. (2005). Differentiated assessment strategies: One tool doesn't fit all. California: Corwin Press.

Council of Europe. (2001). Common European Framework of Reference for Language: Learning, Teaching, Assessment. Cambridge: Cambridge University Press.

Davis, K., Christodoulou, J., Seider, S., \& Gardner, H. (2011). The Theory of Multiple Intelligences. In Sternberg R. J., and Kaufman S. B. (eds), The Cambridge handbook of intelligence, New York, NY: Cambridge University Press, pp. 485-503.

Dörnyei, Z. (2003). Questionnaires in Second Language Research: Construction, Administration and Processing. Mahwah: Lawrence Erlbaum Associates.

Enever, J., Moon, J., \& Raman, U. (2009). Young Learner English Language Policy and Implementation: International Perspectives. Garnet Publishing Ltd., 38(3), 504-506.

Evgeni, D. (2016). Differentiated instruction: The effects on student achievement and motivation in an EFL Greek primary school context. Unpublished Master's dissertation. Patras: Hellenic Open University. Retrieved 16 December 2019 from EAP Digital Dissertation Database.

Eyres, I. (1996). Snjezana i Sedam Patuljaka: Developing language through writing bilingual texts. In Bearne E. (ed), Differentiation and diversity in the primary school. London: Routledge, pp.181-192.

Finch, A. (2007). 'Involving language learners in assessment: A new paradigm'. English Language Assessment, 1(1), 39-58. Retrieved 29 June 2020 from: http://www.finchpark.com/arts/Involving_students_in_assessment_2007.pdf.

Gardner, H. (1999). Intelligence Reframed. New York: Basic Books.

Gabrielatos, C. (2002). EFL writing: product and process. ERIC, ED476839. Available at: http:// www.gabrielatos.com/Writing.pdf (accessed 25 August 2019).

Gregory, G. H., \& Chapman, C. (2012). Differentiated instructional strategies: One size doesn't fit all. California Corwin Press.

Grigorenko, E., \& Sternberg, R. (1997). Styles of thinking, abilities and academic Performance. Exceptional Children, 63(8), 295-312.

Grimes, K. J., \& Stevens, D. D. (2009). Glass, bug, mud. Phi Delta Kappan, 90(9), 677-680. https://doi.org/10.1177/003172170909000914

Hall, T. (2002). Differentiated instruction. Wakefield, MA: National Center on 
Assessing the General Curriculum. Available at http://www.principals.in/uploads/pdf/Instructional_Strategie/DI_Marching.pdf (accessed 6 January 2020).

Hall, T., Vue, G., Strangman, N., \& Meyer, A. (2003). Differentiated instruction and implications for UDL implementation. Wakefield, MA: National Center on Accessing the General Curriculum. Available at http://aem.cast.org/about/publications/2003/ncac-differentiated-instruction-udl.html (accessed 7January 2020).

Hamayan, E. V. (1995). Approaches to Alternative Assessment. Annual Review of Applied Linguistics, 15, 212-226.

Hamidi, E. (2010). Fundamental Issues in L2 Classroom Assessment Practices. Academic Leadership: The Online Journal, 8(2), Article 21. Available at https://scholars.fhsu.edu/alj/vol8/iss2/21/?fbclid=IwAR2nr1onMHwA56ReCovlHyzQFgkjw QqMmmTw8gBCNVLqzBGNKg6X_qW2s2c (accessed 8 January 2020).

Hancock, C. R. (1994). Alternative Assessment and Second Language Study: What and Why?. ERIC Digest: ED376695. Available at http://files.eric.ed.gov/fulltext/ED376695.pdf (accessed 23 February 2020).

Harmer, J. (1991). The practice of English language teaching (New ed.). New York: Longman.

Harmer, J. (2007). The Practice of English Language Teaching. Essex: Pearson Longman.

Hasan, M., \& Akhand, M. (2011). Approaches to Writing in EFL/ESL Context: Balancing Product and Process in Writing Class at Tertiary Level. Journal of NELTA, 15(1-2), 77-88. https://doi.org/10.3126/nelta.v15i1-2.4612

Heacox, D. (2002). Differentiating instruction in the "regular" classroom: How to reach and teach all learners, grades 3-12. Minneapolis, MN: Free Spirit Publishing.

Heacox, D. (2012). Differentiating Instruction in the Regular Classroom: How to Reach and Teach All Learners (Updated Anniversary Edition). Minneapolis, MN: Free Spirit Publishing.

Hertberg-Davis, H. (2009). Myth 7: Differentiation in the Regular Classroom Is Equivalent to Gifted Programs and Is Sufficient: Classroom Teachers Have the Time, the Skill, and the Will to Differentiate Adequately. Gifted Child Quarterly, 53(4), 251-253. https://doi.org/10.1177/0016986209346927

Hughes, A. (2003). Testing for language teachers (2 ${ }^{\text {nd }}$ ed.). Cambridge: Cambridge University Press.

Hyland, K. (2003). Second language writing. New York: Cambridge University Press.

Hyland, K. (2004). Genre and second language writing. Ann Arbor: University of Michigan Press. 
Hyland, K. (2013). Teaching and Researching Writing. London/New York: Routledge.

Kanevsky, L. (2011). Deferential Differentiation: What Types of Differentiation Do Students Want?. Gifted Child Quarterly, 55(4), 279-299. Available at: http://www.vodppl.upm.edu.my/uploads/docs/deferential\%20differentiat ion\%20for\%20gifted\%20children.pdf (accessed 10 December 2019).

Kingore, B. (2004). Differentiation: Simplified, realistic, and effective. Austin, TX: Professional Associates Publishing.

Knowles, G. (2009). Ensuring Every Child Matters. London: Sage.

Krashen, S. D. (1982). Principles and practice in second language acquisition. Oxford, UK: Pergamon Press.

Krashen, S. (1985). The input hypothesis: Issues and implications. London: Longman.

Kroll, B. (ed.) (1990). Second language writing: research insights for the classroom. Cambridge: Cambridge University Press.

Kurk, G., \& Atay, D. (2007). Students' writing apprehension. Journal of Theory and Practice in Education, 3(1), 12-13.

Lalande, J. (1982). Reducing composition errors: An experiment. Modern Language Journal, 66(2), 140-149.

Lawrence-Brown, D. (2004). Differentiated instruction: Inclusive strategies forstandards based learning that benefits the whole class. American Secondary Education, 32(3), 34-62.

Lee, I. (2013). Strategies of assessment for learning in the L2 classroom. Language Education and Acquisition Research Network (LEARN) Journal, 1(2), 1-11.

Leki, I. (1990). Potential Problems with Peer Responding in ESL Writing Classes. The CATESOL Journal, 3(1), 5-19. Available at:http://www.catesoljournal.org/wp-content/uploads/2016/11/CJ3_leki.pdf?fbclid=IwAR1X2 v_Q4MZQBbXDcptfWq_qZHV0yFNzySA2h1SC4BQSE9HiBy4co2w8g6A (accessed 18 December 2017).

Locke, D. C., \& Bailey, D. F. (2014). Increasing Multicultural Understanding. Thousand Oaks, CA:Sage Publications. https://doi.org/10.4135/9781483319582

Mertler, C. A. (2001). Designing scoring rubrics for your classroom. Practical assessment, research \& evaluation, 7(25). Available at: http://PAREonline.net/getvn.asp?v=7\&n=25 (accessed at 22 April 2020)

Moon, J. (2000). Children Learning English. Oxford: MacMillan Education.

Murray, D. M. (1980). Writing as process: How writing finds its own meaning. In Donovan T.R. and McClelland B.W. (eds), Eight approaches to teaching composition. Urbana, IL: National Council of Teachers of English, pp. 3-20. 
Nitko, A. J. (2001). Educational assessment of students ( ${ }^{\text {rd }}$ ed.). Upper Saddle River, NJ: Merrill.

Nordlund, M. (2003). Differentiated Instruction: Meeting the Needs of All Students In Your Classroom. Lanham MD: Scarecrow Press.

Nunan, D. (1999). Second Language Teaching and Learning. Boston, MA: Heinle and Heinle Publishers.

Pedagogical Institute. (2003). Revised unified Greek curriculum for foreign language teaching. Athens: Pedagogical Institute and Greek Ministry of National Education. Retrieved March 32021 from http://www.pi-schools.gr/download/programs/depps/fek304.pdf

Price, M. (2005). Assessment Standards: The Role of Communities of Practice and the Scholarship of Assessment. Assessment \& Evaluation in Higher Education, 30(3), 215-230.

Reid, J. M. (1993). Teaching ESL Writing. Englewood Cliffs, NJ: Prentice Hall Regents.

Richards, J. C. (2001). Curriculum Development in Language Teaching. New York, NY: Cambridge University Press.

Richards, J. C., \& Renandya, W. A. (2003). Methodology in language. An anthology of current practice (3rd ed.). Cambridge: Cambridge University Press

Roberts, J. L., \& Inman, T. F. (2013). Teacher's Survival Guide: Differentiating Instruction in the Elementary Classroom. Waco, TX: Prufrock Press Inc.

Santangelo, T., \& Tomlinson, C. A. (2012). Teacher educators' perceptions and use of Differentiated Instruction practices: An exploratory investigation. Action in Teacher Education, 37(4), 309-327.

Spinthourakis, J. A. (2004). Introduction to key curriculum development concepts. In Ayakli C., Karavas K., Manopoulou- Sergi E and Spinthourakis J. A. (eds), Course Design and Evaluation. Patras: Hellenic Open University, pp. 19-79.

Srichanyachon, N. (2011) 'A Comparative Study of Three Revision Methods in EFL Writing'. Journal of College Teaching \& Learning, 8(9), 1-8.

Steele, V. (2004). Product and process writing. Available at: http://www.englishonline.org.cn/en/teachers/workshops/teaching-writing/teaching-tips/ product-process (accessed 13 April 2016).

Stradling, B., \& Saunders, L. (1993). Differentiation in practice: Responding to the needs of all pupils. Educational Research, 35(2), 127-137. https://doi.org/10.1080/0013188930350202

Sternberg, R. J. (2003). Giftedness According to the Theory of Successful Intelligence. In Colangelo N and Davis G (eds.), Handbook of Gifted Education. Boston, MA: Allyn and Bacon, pp. 88-99.

Subban, P. (2006). Differentiated Instruction: A Research Basis. International education journal, 7(7), 935-947. 
Tan, C. (2004). An Evaluation of the Communicative Approach for the Teaching of the General Paper in Singapore. Journal of Language and Learning: An International Journal for Language and Education Studies, 2(1), 13-26.

Taylor, B. (1981). Teaching Composition to Low Level ESL Students. TESOL Quarterly, 10(3), 309-319.

Taylor, D. (1994). Inauthentic Authenticity or Authentic Inauthenticity?. The Electronic Journal for English as a Second Language, 1(2), 1-11. Available at http://www.tesl-ej.org/wordpress/issues/volume1/ej02/ej02a1/?wscr $\quad$ (accessed 20 November 2019).

Thakur, K. (2014). Differentiated Instruction in the Inclusive Classroom. Research Journal of Educational Sciences, 2(7), 10-14.

Theroux, P. (2004). Differentiating instruction [online]. Alberta, CA: Enhance Learning with Technology Web site. Available at http://members.shaw.ca/priscillatheroux/differentiating.html (accessed 5 November 2019).

Todd, R. W. (2002). Using Self - Assessment for Evaluation'. English Teaching Forum, 40(1), 16-19. Available at https://eric.ed.gov/?id=EJ671628 (accessed 9 March 2017).

Tomlinson, C. A. (1999). Differentiated classroom: Responding to the needs of all learners. Alexandria, VA: Association for Supervision \& Curriculum Development.

Tomlinson, C. A. (2001). How to differentiate instruction in mixed-ability classrooms. Alexandria, VA: Association for Supervision and Curriculum Development.

Tomlinson, C. A. (2001b). Differentiated Instruction in the regular classroom: What does it mean? How does it look?.Understanding Our Gifted, 14(1), 3-6.

Tomlinson, C. A. (2003). Fulfilling the Promise of the Differentiated Classroom: Strategies and Tools for Responsive Teaching. Alexandria, VA: Association for Supervision and Curriculum Development.

Tomlinson, C., \& McTighe, J. (2006). Integrating differentiated instruction and understanding by design: Connecting content and kids. Alexandria, VA: Association for Supervision and Curriculum Development.

Tomlinson, C. A. (2014) The Differentiated Classroom Responding to the Needs of All Learners $\left(2^{\text {nd }}\right.$ ed.). Alexandria, VA: Association for Supervision and Curriculum Development.

Tomlinson, C. A., \& Callahan, C. (1992). Contributions of gifted education to general education in a time of change. Gifted Child Quarterly, 36(4), 183-188.

Torrance, E. (1995). Insights about creativity. Questioned, rejected, ridiculed, ignored. Educational Psychology Review, 7(3), 313-322.

Tsagari, D. (2008). Assessment Literacy of EFL Teachers in Greece - Current Trends and 
Future Prospects.10 May, $5^{\text {th }}$ Annual Conference of the European Association of Language Testing and Assessment (EALTA). Athens, Greece. Available at: http://www.ealta.eu.org/conference/2008 (accessed 23 February 2020).

Vygotsky, L. S. (1978). Mind in Society: The Development of Higher Psychological Processes. Cambridge, MA: Harvard University Press.

Wentzel, K. R., McNamara-Barry, C., \& Caldwell, K. A. (2004). Friendships in Middle School: Influences on Motivation and School Adjustment. Journal of Educational Psychology, 96(2), 195-203.

White, R., \& Arndt, V. (1991). Process Writing. London \& New York: Longman.

Wormeli, R. (2007). Differentiation: From: planning to practice, grades 6-12. Portland, ME: Stenhouse Publishers.

Yang, M., Badger, R., \& Yu, Z. (2006). A Comparative Study of Peer and Teacher Feedback in a Chinese EFL Writing Class. Journal of Second Language Writing, 15(3), 179-200.

Yoshimura, H. (2009). Effects of connecting reading and writing and a checklist to guide the reading process on EFL learners' learning about English writing. Procedia Social and Behavioral Sciences, 1(1), 1871-1883.

Zamel, V. (1982). Writing: The Process of Discovering Meaning. TESOL Quarterly, 16(2), 195-209.

Zare-ee, A. (2009). The effects of teaching genre moves on EFL learners' performance in letter writing. Pazhuhesh-e Zabanha-ye Khareji, 49 (Special Issue): 43-64. Available at https://pdfs.semanticscholar.org/3fdf/de550bfbc11953e83daf02d642c6cb0d0ab4.pdf (accessed 3 April 2017).

Zhao, H. (2010). Investigating learners' use and understanding of peer and teacher feedback on writing: A comparative study in a Chinese English writing classroom. Assessing Writing, 15(1), 3-17.

\section{Copyright Disclaimer}

Copyright for this article is retained by the author(s), with first publication rights granted to the journal.

This is an open-access article distributed under the terms and conditions of the Creative Commons Attribution license (http://creativecommons.org/licenses/by/4.0/). 